\title{
Seasonal benefits of a natural propolis envelope to honey bee immunity and colony health
}

\author{
Renata S. Borba ${ }^{1, \star}$, Karen K. Klyczek², Kim L. Mogen² and Marla Spivak ${ }^{1}$
}

\begin{abstract}
Honey bees, as social insects, rely on collective behavioral defenses that produce a colony-level immune phenotype, or social immunity, which in turn impacts the immune response of individuals. One behavioral defense is the collection and deposition of antimicrobial plant resins, or propolis, in the nest. We tested the effect of a naturally constructed propolis envelope within standard beekeeping equipment on the pathogen and parasite load of large field colonies, and on immune system activity, virus and storage protein levels of individual bees over the course of a year. The main effect of the propolis envelope was a decreased and more uniform baseline expression of immune genes in bees during summer and autumn months each year, compared with the immune activity in bees with no propolis envelope in the colony. The most important function of the propolis envelope may be to modulate costly immune system activity. As no differences were found in levels of bacteria, pathogens and parasites between the treatment groups, the propolis envelope may act directly on the immune system, reducing the bees' need to activate the physiologically costly production of humoral immune responses. Colonies with a natural propolis envelope had increased colony strength and vitellogenin levels after surviving the winter in one of the two years of the study, despite the fact that the biological activity of the propolis diminished over the winter. A natural propolis envelope acts as an important antimicrobial layer enshrouding the colony, benefiting individual immunity and ultimately colony health.
\end{abstract}

KEY WORDS: Social immunity, Apis mellifera, Resin, Antimicrobial peptides

\section{INTRODUCTION}

Social insect colonies may be considered superorganisms, a group of related individuals living in a nest, whose collective behaviors produce a colony-level phenotype, which in turn influences the behaviors of individuals in the nest (Seeley, 1989). Highly social insects' immune defenses function in a similar collective way: at the individual level, an immune response is initiated via cellular or humoral immune pathways (Evans et al., 2006). At the colony level, some individuals perform behaviors that defend and protect the colony against pathogens and parasites (Simone et al., 2009). These behavioral defenses in a honey bee colony include hygienic behavior and grooming (Wilson-Rich et al., 2008), antimicrobial secretions (e.g. the spread of venom on a bee's cuticle; Baracchi et al., 2011), and the collection of antimicrobial compounds (e.g. resins) from the environment (Simone et al., 2009). Combined with

\footnotetext{
${ }^{1}$ Department of Entomology, University of Minnesota, 1980 Folwell Avenue, Saint Paul, MN 55108, USA. ${ }^{2}$ Biology Department, University of Wisconsin-River Falls, 410 S. 3rd Street, River Falls, WI 54022, USA.

*Author for correspondence (rsborba@umn.edu)
}

Received 24 June 2015; Accepted 21 September 2015 the division of labor among individuals (Naug and Smith, 2007; Stroeymeyt et al., 2014), these behavioral defenses produce a colony-level immune phenotype, or social immunity (Cremer et al., 2007), which in turn impacts the immune response of individuals (Otti et al., 2014).

Behavioral, or social, immunity benefits overall colony health and may have less physiological cost to individuals compared with the cost of maintaining a diverse immune system (Evans and Pettis, 2005; Schmid-Hempel, 2005). In honey bees, social immunity plays an important role in reducing parasite establishment and spread within colonies (Arathi et al., 2000; Evans and Spivak, 2010; Simone-Finstrom and Spivak, 2012).

The collection of antimicrobial resins from the environment by honey bees (Simone et al., 2009) and the deposition of these resins into the nest architecture is a fundamental component of bee social immunity. Resin is a plant exudate secreted prophylactically to protect young leaf buds from pathogen infection and herbivore attack. It is composed primarily of antimicrobial compounds (e.g. monoterpenes and flavonoids) that play a major defensive role in the survival of the plant (Langenheim, 2003). Honey bees deposit these plant resins in the nest as a form of cement, called propolis. When honey bees nest in tree cavities, they use propolis to coat the entire inner surface of the nest cavity, constructing a propolis envelope (Seeley and Morse, 1976). However, honey bees do not construct a natural propolis envelope within standard beekeeping equipment because the inner walls of the wooden boxes are smooth and do not elicit propolis deposition behavior. Instead, bees deposit propolis only in dispersed cracks and crevices and not as a continuous envelope (Simone-Finstrom and Spivak, 2010).

Simone et al. (2009) first tested the benefits of a propolis envelope to the bees' immune system by experimentally coating the inside of boxes with a propolis extract solution (ethanolic solution of propolis) to simulate a propolis envelope surrounding small colonies of honey bees. After just 7 days of exposure to the propolisenriched nest environment, the immune-related gene transcription of the bees was significantly lower than that of bees in boxes not enriched with the propolis extract. The bacterial load (eubacterial $16 \mathrm{~S}$ gene expression, which measures internal and external bacteria carried by bees) was also significantly lower in bees in propolisenriched colonies. These results suggested that the propolis reduced the level of immune elicitors in the nest, so that the bees were able to expend less energy on costly immune system activation (Simone et al., 2009).

Other benefits of propolis to honey bee health have been documented. Numerous in vitro studies have demonstrated the inhibitory activity of propolis, and specific compounds within propolis, against the growth of the honey bee bacterial pathogen Paenibacillus larvae and Ascosphaera apis (Antúnez et al., 2008; Bastos et al., 2008; Bilikova et al., 2013; Lindenfelser, 1968; Wilson et al., 2013, 2015). It is not known whether honey bees actually consume propolis, but Johnson et al. (2012) demonstrated 
that when bees were experimentally fed propolis in sucrose syrup, the transcription of three cytochrome $450 \mathrm{~s}$, involved in pesticide detoxification, was induced (Johnson et al., 2006; Mao et al., 2011). The placement of natural propolis in the nest cavity has been positively correlated with brood viability, worker lifespan, honey production, hygienic behavior and pollen stores (Nicodemo et al., 2013, 2014).

Here, we tested the effect of a naturally constructed propolis envelope within standard beekeeping equipment on the strength, and pathogen and parasite load of large field colonies, and immune system activity, virus and storage protein level of individual bees over the course of a year. Our aim was to examine the relative immune and health benefits of the natural propolis envelope from the scale of the individual bee to the level of the entire colony. At the individual level, we hypothesized that the presence of a propolis envelope enshrouding the nest area would result in a decrease in eubacterial load (based on findings from Simone et al., 2009) and possibly virus load. Additionally, we predicted that in response to the lower level of immune elicitors (pathogens and other microbes) within the nest, the immune-related gene expression in bees from colonies with a propolis envelope would be lower compared with that of bees in colonies without the propolis envelope (Simone et al., 2009). At the colony level, we hypothesized that colonies with a propolis envelope would have greater colony strength (more bees and brood; e.g. Nicodemo et al., 2013, 2014) and would have increased winter survivorship. Our findings revealed a significant reduction in the baseline activity of a number of immune-related gene transcripts in individual bees, but no effects on other measured microbes, pathogens or parasites. Colonies with the natural propolis envelope had increased colony strength after surviving the winter in one of the two years of the study. This is the first study to investigate the seasonal benefits of propolis to honey bees, and demonstrates how the collection and deposition of resins into the nest architecture produces a colony-level immune phenotype that impacts individual immunity, and ultimately colony health.

\section{MATERIALS AND METHODS}

Stimulation of propolis envelope construction in field colonies

This experiment was conducted at the University of Minnesota Agricultural Experiment Station in Rosemount, MN, USA. Honey bee colonies were established from packages (Nature's Nectar LLC, MN, USA) and were hived in new 10-frame standard Langstroth equipment in mid-April 2012. In mid-April 2013, a second set of colonies was established from packages to serve as a replication of this experiment. In each replicate, sister queens of Italian derived Apis mellifera ligustica were introduced into each colony to reduce genetic variation. Twelve colonies each year were provided with commercially available propolis traps (Mann Lake Ltd, MN, USA) stapled to the four inner walls of each bee box to encourage the bees to construct a propolis envelope within the nest (propolis envelope treatment; Fig. 1). Another 12 colonies each year served as controls; no propolis trap was provided and the bees deposited propolis in the cracks and crevices within the box where they could (control treatment).

\section{Colony management}

Honey bee colonies were given routine management and supplemental feeding as needed. Pollen substitute and sugar syrup were provided to new package bees in early spring and additional boxes were added in the summer for honey storage when necessary. No sugar syrup was fed to colonies in the autumn and all colonies were left sufficient honey stores to last the northern winter. In September 2012 and 2013, all the colonies were treated to control Varroa mites to avoid confounding the effects of the propolis envelope on colony survivorship with the effects of this parasitic mite. In both years, all the colonies were treated with a commercial thymol-based product (Apigard $^{\circledR}$, Mann Lake Ltd). In 2013, all colonies still had high levels of

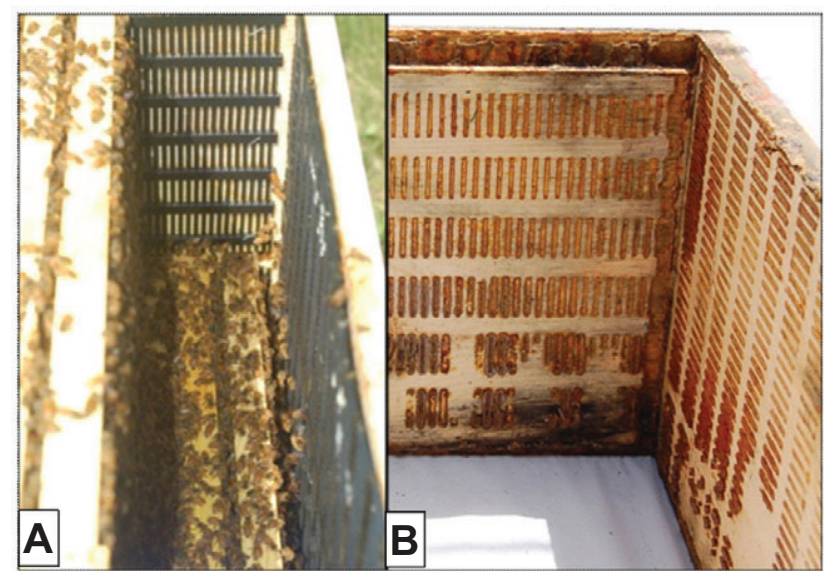

Fig. 1. Propolis envelope treatment box. (A) Propolis traps stapled to the inside walls of a hive to encourage bees to construct a propolis envelope. (B) View of the propolis envelope when traps were removed at the end of the experiment. In each colony, the bees deposited propolis within most of the gaps of each propolis trap (brown lines on the box are the deposited propolis) In a tree cavity, the propolis envelope is contiguous, but bees do not tend to deposit propolis on planed wooden walls in beekeeping equipment, unless lumber is left unfinished.

Varroa (an average of 10.65 mites per 100 bees after the thymol treatment) and, therefore, all received a second miticide treatment with oxalic acid in October (Rademacher and Harz, 2006). No colonies were treated for Nosema spp. Colonies were overwintered in Minnesota in the same apiary as that during summer and autumn, and in the boxes according to the treatment they had received.

\section{Colony-level measurements}

Colony-level measurements were assessed in the summer (first week of July), autumn (last week of September) and following spring (first week of temperatures above $12^{\circ} \mathrm{C}$ in May). The second replicate year of this experiment did not include colony assessments in July. All assessments consisted of: (1) estimating the adult bee population size by counting the number of frames covered with bees for each box (Nasr et al., 1990); (2) estimating the total amount of worker brood by using a grid $\left(2.56 \mathrm{~cm}^{2}\right)$ over a frame and counting the number of squares filled with sealed or unsealed brood (Nasr et al., 1990); (3) collecting a sample of 300 adult bees from the brood area in $70 \%$ ethanol and quantifying Varroa and Nosema spp. levels in the laboratory following previously published methods (Lee et al., 2010; Spivak and Reuter, 2001); (4) inspecting for the presence of clinical symptoms of diseases in the field [e.g. American foulbrood (AFB)-infected larvae, as noted by the presence of sunken wax capping and uncapped cells containing discolored, ropy brood]; and (5) noting colony survivorship as dead or alive. Colony life time was recorded as the number of days from the first day of the experiment (day 1) until the inspection date when the colony was found to be dead, or until the last day of the experiment for colonies that did not die.

\section{Sample collection of bees for gene expression analysis}

During the colony assessments, newly emerged bees (noted by their location near emerging pupae and their fuzzy appearance; Human et al., 2013) were painted using enamel paint markers, and 20 bees per hive were collected after 6 days. The marked, 7-day-old bees were stored in a $-80^{\circ} \mathrm{C}$ freezer until analysis. Immunocompetence in bees increases from emergence to day $7-8$ of adult life, at which time it is thought that their immune system is fully capable of starting an immune response (Wilson-Rich et al., 2008). We sampled 7-day-old bees because immune activity becomes more variable after 8 days until bees become foragers, when immunity is highly decreased (Amdam et al., 2005; Simone et al., 2009).

We analyzed the gene expression level of the following using real-time PCR. For the immune response, we measured four antimicrobial peptides (hymenoptaecin, abaecin, defensin-1 and defensin-2), the NF-kB 
transcription factor of the Immune Deficiency (IMD) pathway (relish), and phenoloxidase. We estimated the bacterial load of the colony by measuring the gene expression of the eubacterial $16 \mathrm{~S}$ gene (16S rRNA) in individual bees (interior and exterior bacteria carried by bees) using a universal primer (Evans et al., 2006; Simone et al., 2009) to test for the effect of propolis on bacterial level. The expression of vitellogenin $(\mathrm{Vg})$ was measured as a marker of nutritional status, as it is the main storage protein for bees and a precursor for other proteins. Additionally, Vg is used by young adult bees (5-16 days old) during the synthesis of the antimicrobial secretion royal jelly, which they use to feed queens and young larvae (Amdam et al., 2003). Finally, we measured levels of the three most common viruses in honey bee colonies: deformed wing virus (DWV), Israeli acute paralysis virus (IAPV) and black queen cell virus (BQCV).

\section{Real-time PCR methods}

Total RNA was isolated from individual bee abdomens of 7-day-old marked bees using TRIzol reagent (Ambion, Austin, TX, USA) following the manufacturer's protocol. The quality and quantity of total RNA were measured using a NanoDrop2000 instrument (Thermo Scientific Inc., Grand Island, NY, USA) and $3.5 \mu \mathrm{g}$ of each sample was used for cDNA synthesis. Prior to cDNA synthesis, RNA was treated with DNase I (Ambion) and reverse transcription for cDNA synthesis was carried out using Superscript II (Invitrogen, Grand Island, NY, USA). Complementary DNA was diluted 1:3 with RNase- and DNase-free water. Relative quantification of viral levels, candidate genes used for the immune system response, bacterial load and blood storage protein $(\mathrm{Vg})$ were analyzed via real-time PCR (Bio-Rad CFX96). Samples for real-time PCR were prepared using iTaq Universal SYBR Green Supermix (Bio-Rad, Hercules, CA, USA). Primer sequences used for this experiment were selected from the literature when available and optimal annealing temperature was met (Table S1). Otherwise, primers were designed using MacVector version 12.5.1 and specificity was confirmed using primerBLAST.

\section{Seasonal antimicrobial activity of propolis}

Honey bees in Minnesota do not forage for resin (or for any resources) from October to April. Therefore, we tested whether the resin deposited within the hive in September maintained its bioactivity over the winter, until April of the following year. A high throughput bacterial growth assay was performed to assess the inhibitory activity of propolis on the growth of the honey bee bacterial pathogen P. larvae. A total of nine propolis samples were collected from the traps of three propolis envelope treatment colonies in September and in the following April. Three colonies from the propolis envelope treatment group were randomly selected and three propolis samples $(3-5 \mathrm{~g}$ each) were collected from each colony by detaching the traps from the wall and scraping the propolis using a hive tool. Bioactive compounds of propolis (approximately $1 \mathrm{~g}$ of each propolis sample) were extracted in $1 \mathrm{ml}$ of acetonitrile. Propolis extract concentrations $(\mathrm{w} / \mathrm{v})$ were calculated by air drying a $200 \mu \mathrm{l}$ aliquot of the propolis acetonitrile extract using a speedvac concentrator and dividing the mass of the precipitate by the initial volume of $200 \mu 1$. Paenibacillus larvae (from stock strains obtained from the USDA Agricultural Research Service culture collection, NRRL no. B-2605) were cultured in brain/heart infusion broth and the bacterial growth assay was conducted following the methods of Wilson et al. (2015). Propolis extracts were diluted in acetonitrile to final concentrations ranging from 175 to $8 \mathrm{mg} \mathrm{l}^{-1}$, transferred into 96-well plates, dried under nitrogen gas, and resolubilized in $100 \mu \mathrm{l}$ of brain/heart infusion broth for $15 \mathrm{~min}$. Paenibacillus larvae liquid culture was transferred into the well plates (creating a 1:100 dilution of $P$. larvae in each well), and well plates were incubated at $37^{\circ} \mathrm{C}$ and $400 \mathrm{rpm}$ for $6 \mathrm{~h}$. Bacterial growth inhibition was evaluated in 96 -well plates by measuring turbidity (optical density $\mathrm{OD}_{600}$ at time $0 \mathrm{~h}$ subtracted from time $6 \mathrm{~h}$ ) of treated cultures relative to untreated controls using a microplate spectrophotometer.

\section{Statistical analysis}

Colony-level data analysis

Colony-level measurements (adult population size, worker brood size, Varroa and Nosema levels) were compared between treatment groups (propolis envelope colonies and control colonies) using two-tailed $t$-tests
( $\mathrm{R}$ version 2.15). Colony status was recorded at each hive inspection as dead or alive. For colonies found to be dead after the winter, the date of death was recorded as the first spring inspection day, as no inspections of the colonies were made from November to April. Colony survivorship was analyzed using the non-parametric Kaplan-Meier method and Wilcoxon rank-sum test, using JMP ${ }^{\circledR}$ software (Cary, NC, USA), to test differences between groups.

\section{Gene expression data analysis}

$C_{\mathrm{t}}$ values were collected based on the default Bio-Rad CFX threshold search criteria. The relative expression of target genes was normalized to the average of two reference genes:

$$
\left(\Delta C_{\mathrm{t}}=(\bar{x} \text { (reference genes) } C t-\text { target gene } C t)\right),
$$

and an $F$-test (ANOVA) was performed using $\mathrm{R}$ version 2.15 , with colony as a random factor and treatment group as a fixed effect.

\section{Seasonal variability in gene expression}

Seasonal variability of the immune gene expression was obtained as the standard deviation of all $\Delta C_{\mathrm{t}}$ values for each gene separately. The relative expression for each gene was combined for all sampling periods (i.e. from July 2012 to May 2013 for the 2012-2013 experimental year, and from September 2013 to May 2014 for the 2013-2014 experimental year) and the difference in variability was compared between treatment groups by the Levene test using R version 2.15 .

\section{Bacterial inhibition assay}

An $\mathrm{IC}_{50}$ for the propolis inhibition assay was calculated by fitting a fourparameter logistic equation to the sigmoidal inhibition curves using Systat software version 12.5 (San Jose, CA, USA). The $\mathrm{IC}_{50}$ values of propolis samples from September and April were compared using a two-tailed $t$-test ( $\mathrm{R}$ version 2.15)

\section{RESULTS}

\section{Effects of propolis on colony-level measurements}

The experiment was replicated over 2 years. The first set of 24 colonies (12 with propolis envelopes, 12 without) was followed from July 2012 to early May 2013. A second, new set of 24 colonies was followed from September 2013 to early May 2014.

\section{Colony strength}

Brood areas were similar between the treatment groups during the summer and autumn inspections each year. By the spring of the first year, May 2013, colonies with a propolis envelope had significantly more worker brood compared with the control colonies $\left(t_{12}=2.19\right.$, two-tailed, $P=0.04$ ), but this positive trend was not significant in the second replicate of the experiment by May 2014 (Fig. 2A). There were no significant differences in the population size of colonies (adult worker bees) in the summer, autumn or spring in both replications of the experiment (Fig. 2B).

\section{Colony survivorship}

Colony survivorship (colony life time from April until May of the following year, measured in days) was significantly higher in colonies with a propolis envelope compared with control colonies in the 2012-2013 experimental year ( $P=0.04$; Fig. 3). Colony survivorship was the same between groups in the subsequent experimental year, 2013-2014.

\section{Parasite and pathogen levels}

As expected, because mite levels were controlled during autumn treatments, there was no significant difference in levels of Varroa mites between treatment groups before or after autumn treatment (thymol-based and oxalic acid) and by the following spring in either 

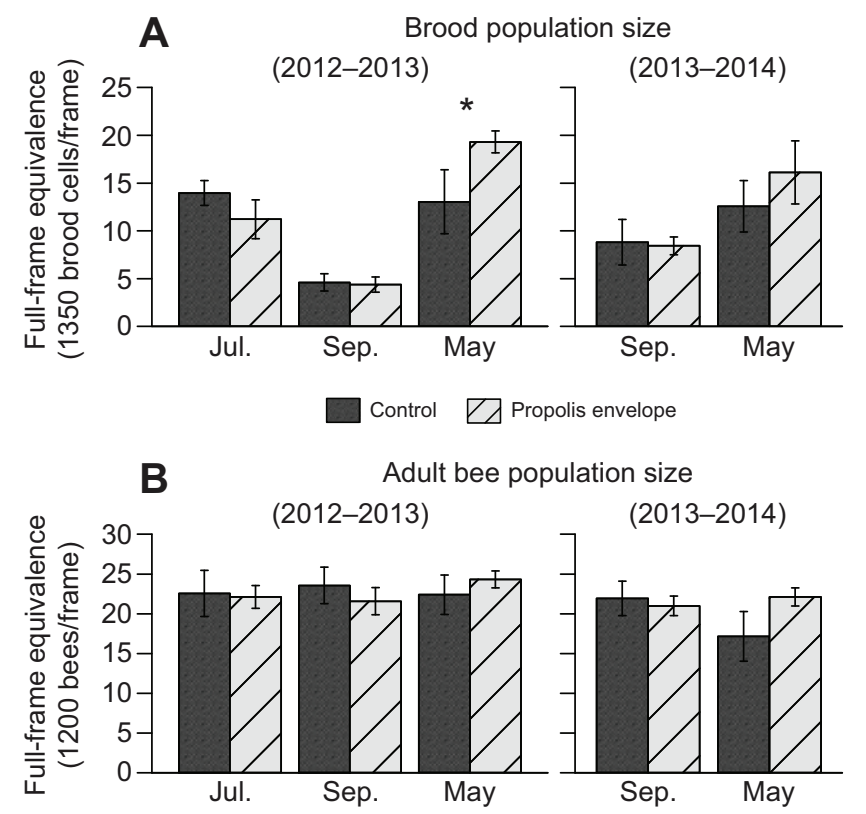

Fig. 2. Colony strength. The presence of a propolis envelope benefits colony strength in early spring. Mean ( \pm s.e.m.) full-frame equivalents are shown for (A) brood population size (1350 worker brood cells/frame) and (B) adult bee population size (1200 adult bees/frame), for the months of July 2012 ( $N=19$ colonies), September 2012 ( $N=17$ colonies), May 2013 ( $N=14$ colonies), September 2013 ( $N=24$ colonies) and May 2014 ( $N=16$ colonies). Significant differences between controls and propolis envelope treatment colonies are indicated with an asterisk $\left({ }^{*} P<0.05\right)$.

replication of the experiment (Fig. 4A). In September of 2012, the colonies with a propolis envelope had lower levels of Nosema spp. but the difference was only marginally significant $\left(t_{16}=1.84\right.$, twotailed, $P=0.08$ ). Overall, all levels of Nosema spp. were generally below 1 million spores per bee in both years, and no colonies received treatment for Nosema spp. (Fig. 4B).

\section{Effects of propolis on virus levels}

There was no significant difference in the levels of DWV, IAPV and $\mathrm{BQCV}$ in bees from colonies with the propolis envelope compared with bees from control colonies in the first replicate (samples from September 2012 and May 2013), and in the autumn of the second replicate (September 2013). In May 2014, bees from colonies with a propolis envelope had lower levels of BQCV, but the difference was only marginally significant $\left(F_{1,11}=3.45, P=0.09\right.$; Fig. 5).

\section{Effects of propolis on individual bee immune system Summer and autumn}

The transcription levels of two of the six immune gene transcripts, hymenoptaecin and abaecin, in bees from colonies with a propolis envelope were significantly lower than in bees from control colonies in July $2012\left(F_{1,16}=5.77, P=0.03\right.$; and $F_{1,16}=20.76, P=0.0003$, respectively; Fig. 6A).

By September 2012 (Fig. 6B), all six measured gene transcripts for the immune system response (hymenoptaecin, abaecin, defensin-2, defensin-1, relish and phenoloxidase) were expressed at significantly lower levels in bees from the propolis envelope treatment than in bees from the control colonies $\left(F_{1,16}=5.98\right.$, $P=0.03 ; F_{1,16}=11.14, P=0.004 ; F_{1,16}=6.29, P=0.02 ; F_{1,16}=12.04$, $P=0.003 ; F_{1,16}=35.39, P<0.0001 ;$ and $F_{1,16}=14.16, P=0.002$,

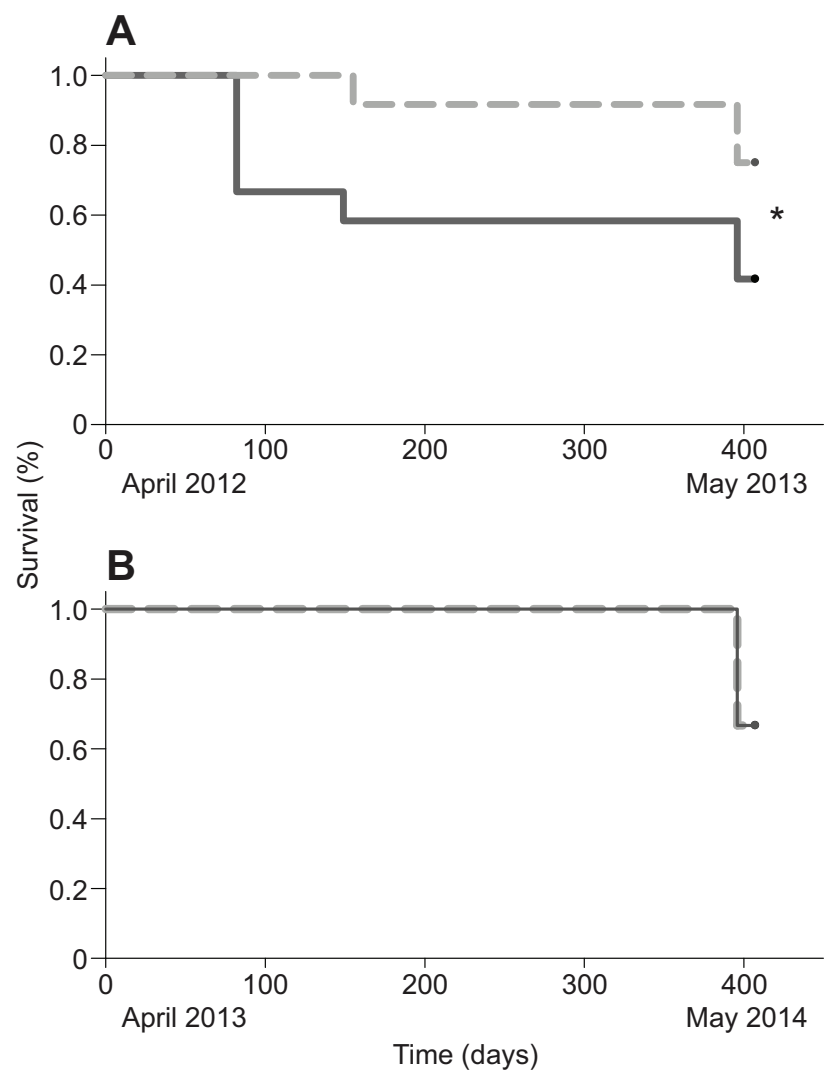

Fig. 3. Colony survivorship. Kaplan-Meier survivorship curves comparing survival (proportion of colonies alive) of control colonies (solid line) and colonies with a propolis envelope (dashed line) for (A) the 2012-2013 experimental year and (B) the 2013-2014 experimental year. Twelve colonies for each treatment were used in both replicates at the beginning of the experiment. Significant differences between groups, determined by Wilcoxon rank-sum test, are indicated by an asterisk $\left({ }^{\star} P<0.05\right)$.

respectively). In September 2013, in the second replicate of the experiment, bees from the propolis envelope colonies had significantly lower levels of hymenoptaecin and abaecin (Fig. 6D) compared with bees from the control colonies $\left(F_{1,9}=5.71, P=0.004\right.$; and $F_{1,9}=7.82, P=0.02$, respectively). Samples were not collected in July 2013.

\section{Spring of the following year}

In the first replicate, by May 2013, bees in the propolis envelope treatment showed significantly higher transcription of three immune-related genes: defensin-1, relish and phenoloxidase $\left(F_{1,9}=24.18, P=0.0006 ; F_{1,9}=14.90, P=0.004 ;\right.$ and $F_{1,9}=11.06$, $P=0.007$, respectively; Fig. $6 \mathrm{C}$ ), and there were no differences in levels of the other immune gene transcripts. In May 2014, there were no differences between bees in the treatment groups for any of the immune transcript levels (Fig. 6E).

\section{Effects of propolis on the seasonal variation of the immune response}

Variability in immune gene expression was obtained as the standard deviation of all $\Delta C_{\mathrm{t}}$ values (summer, autumn and spring pooled together) for each gene separately. The relative expression of each gene was combined for all sampling periods (i.e. from July 2012 to May 2013 for the 2012-2013 experimental year, and from September 2013 to May 2014 for the 2013-2014 experimental 
A

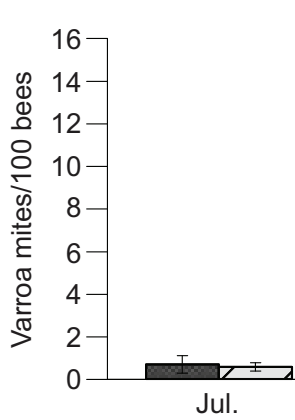

(2012-2013)

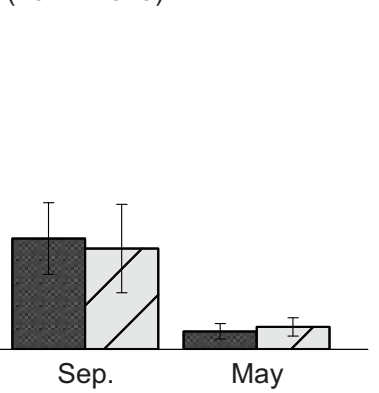

Varroa

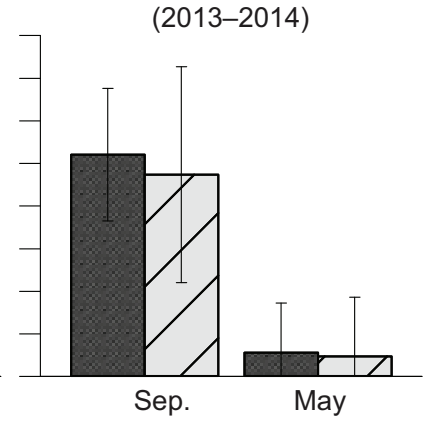

Fig. 4. Infestation levels of parasites (Varroa mites) and pathogens (Nosema spp.) in honey bee colonies.

(A) Number of parasitic Varroa destructor mites per 100 bees and (B) number of Nosema spp. spores per bee for the months of July 2012 ( $N=19$ colonies), September 2012 ( $N=17$ colonies), May 2013 ( $N=14$ colonies), September 2013 ( $N=24$ colonies) and May 2014 ( $N=16$ colonies). Data are means \pm s.e.m., 12 colonies per treatment.

Control $\square$ Propolis envelope

B

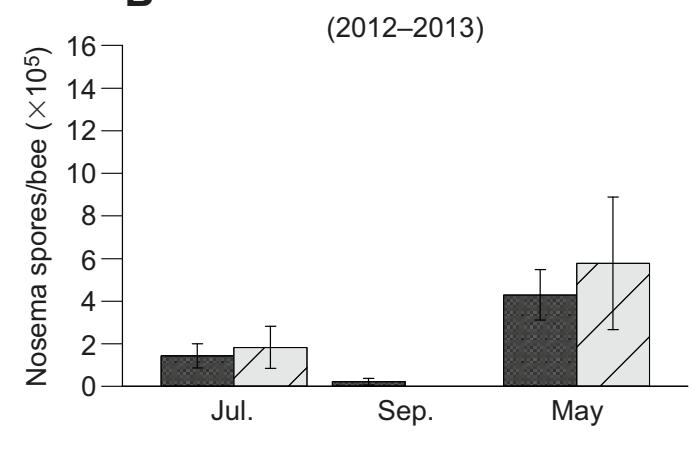

Nosema

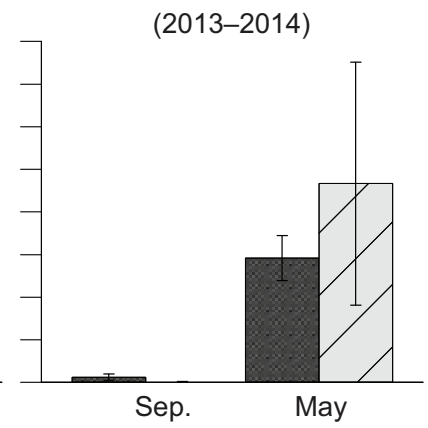

year) and the difference in variability was compared between treatment groups by the Levene test. From July 2012 to May 2013, there was significantly less variation in the gene expression of five immune genes (hymenoptaecin, abaecin, defensin-1, defensin-2 and relish) in bees from colonies with a propolis envelope compared with bees from the control colonies. In contrast, there was significantly higher variation in levels of phenoloxidase over that season in bees from colonies with a propolis envelope compared with control colonies. In the second replicate of the experiment, from September 2013 to May 2014, bees from colonies with a propolis envelope had significantly lower variation in hymenoptaecin, abaecin, defensin-1, defensin-2 and phenoloxidase gene expression levels. Expression of one of the genes, relish, was lower in bees from colonies with a propolis envelope compared with levels in control colonies, but the difference was only marginally significant (Table 1). Thus in general, the seasonal

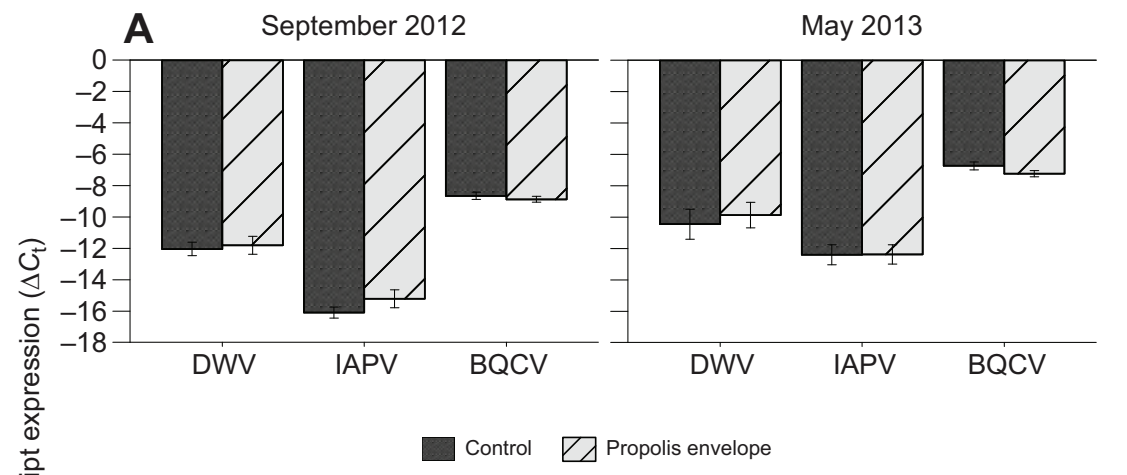

B September 2013 $\stackrel{\substack{0 \\ 0}}{\square}$
May 2014

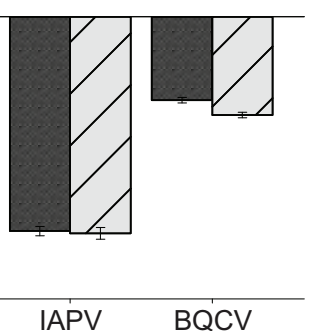

Fig. 5. Relative expression levels of virus genes in honey bee colonies. Transcript levels (means \pm s.e.m.) of deformed wing virus (DWV), Israeli acute paralysis virus (IAPV) and black queen cell virus (BQCV), normalized to the reference genes actin and RPS- 5 ( $N=20$ biological replicates per colony and 6 colonies per treatment), are shown for (A) September 2012 and May 2013, and (B) September 2013 and May 2014 for control and propolis envelope treatment colonies. Negative levels indicate viral load expression was lower than reference gene expression. 

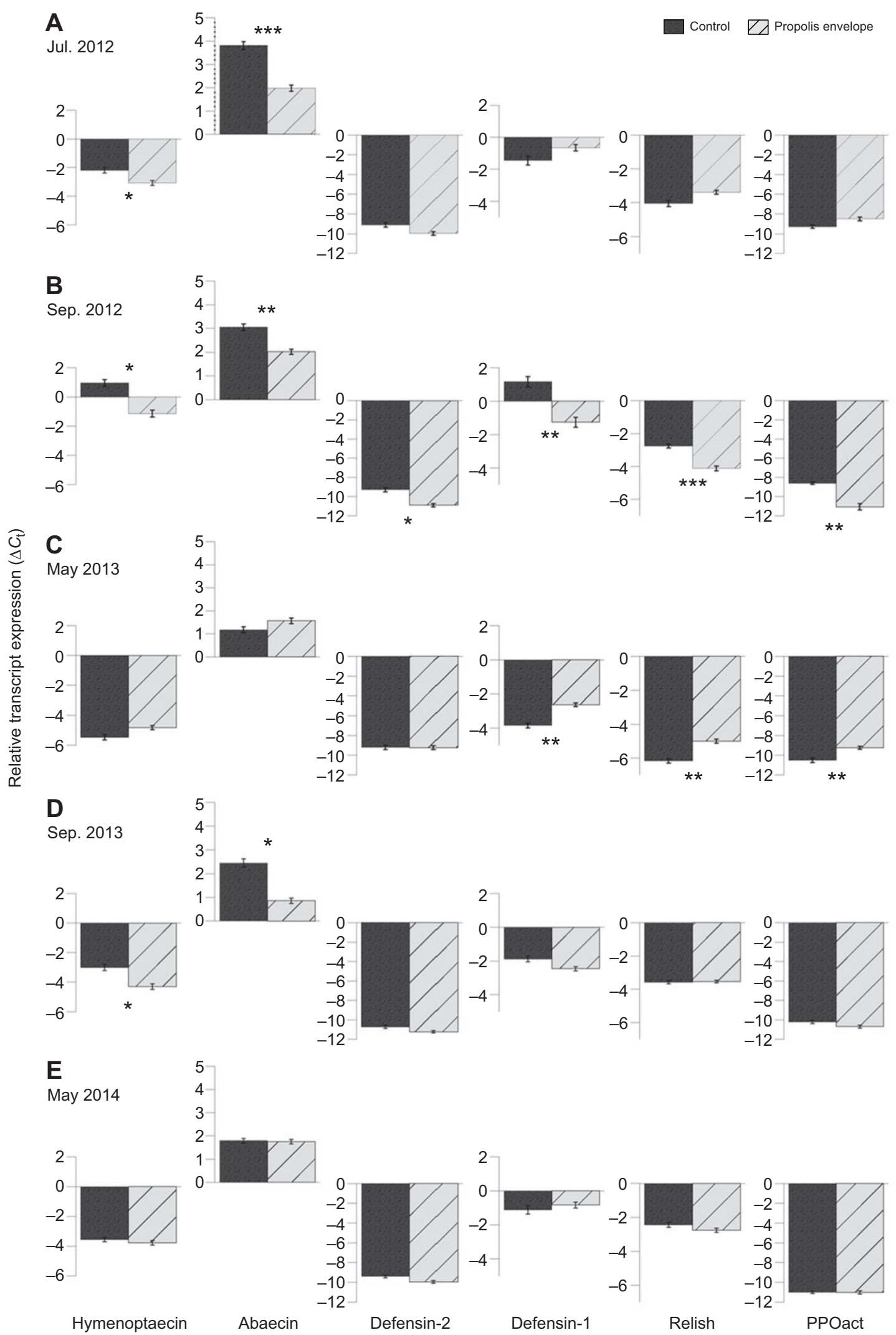

Fig. 6. Relative expression levels of antimicrobial peptides, the NF-kB transcription factor relish and phenoloxidase in honey bee colonies. Transcript levels (means \pm s.e.m.) of hymenoptaecin, abaecin, defensin-2, defensin-1, relish and phenoloxidase (PPOact), normalized to the reference genes actin and RPS5 ( $N=20$ biological replicates per colony and 6 colonies per treatment), are shown for (A) July 2012, (B) September 2012, (C) May 2013, (D) September 2013 and (E) May 2014 for control and propolis envelope treatment colonies. Significant differences between groups, determined by two-tailed $t$-test with colonies as random variables, are indicated by asterisks $\left({ }^{*} P<0.05,{ }^{* *} P<0.01,{ }^{* *} P<0.001\right)$. A low value indicates lower gene expression (e.g. in July 2012 , colonies with a propolis envelope had significantly lower expression of both hymenoptaecin and abaecin relative to controls). 
Table 1. Variability of the combined immune gene transcription data for each experimental period: 2012-2013 and 2013-2014

\begin{tabular}{|c|c|c|c|}
\hline & \multicolumn{2}{|c|}{$\begin{array}{l}\text { Absolute deviation from the } \\
\text { group median }\end{array}$} & \multirow[b]{2}{*}{ Levene test } \\
\hline & Control & Propolis envelope & \\
\hline \multicolumn{4}{|l|}{$2012-2013$} \\
\hline Hymenoptaecin & 2.86 & 1.90 & $\begin{array}{l}F_{1,729}=56.3313 \\
P<0.0001\end{array}$ \\
\hline Abaecin & 1.54 & 1.10 & $\begin{array}{l}F_{1,723}=35.4422 \\
P<0.0001\end{array}$ \\
\hline Defensin-2 & 1.96 & 1.72 & $\begin{array}{l}F_{1,733}=5.7569 \\
P=0.02\end{array}$ \\
\hline Defensin-1 & 2.30 & 1.55 & $\begin{array}{l}F_{1,368}=26.8223 \\
P<0.0001\end{array}$ \\
\hline Relish & 1.54 & 0.98 & $\begin{array}{l}F_{1,372}=41.7818 \\
P<0.0001\end{array}$ \\
\hline Phenoloxidase & 1.10 & 1.34 & $\begin{array}{l}F_{1,322}=4.9739 \\
P=0.03\end{array}$ \\
\hline \multicolumn{4}{|l|}{ 2013-2014 } \\
\hline Hymenoptaecin & 1.67 & 1.28 & $\begin{array}{l}F_{1,457}=12.7419 \\
P=0.0004\end{array}$ \\
\hline Abaecin & 1.22 & 0.89 & $\begin{array}{l}F_{1,454}=17.5586 \\
P<0.0001\end{array}$ \\
\hline Defensin-2 & 1.43 & 1.12 & $\begin{array}{l}F_{1,459}=11.1749 \\
P=0.0009\end{array}$ \\
\hline Defensin-1 & 1.42 & 1.15 & $\begin{array}{l}F_{1,263}=5.0091 \\
P=0.0261\end{array}$ \\
\hline Relish & 0.83 & 0.70 & $\begin{array}{l}F_{1,267}=3.5282 \\
P=0.0614\end{array}$ \\
\hline Phenoloxidase & 1.14 & 0.88 & $\begin{array}{l}F_{1,240}=6.1731 \\
P=0.0137\end{array}$ \\
\hline
\end{tabular}

The spread of the immune gene expression data was measured as $z i j=|y i j-\bar{y} i|$ and is reported as the absolute deviation of each immune response $\left(\Delta C_{t}\right)$ and the group median for each gene separately.

variability of the immune gene expression was lower in the sample population from colonies with a propolis envelope than in the sample population from control colonies.

\section{Effects of propolis on eubacterial levels}

Levels of general eubacteria were similar between treatment groups in July 2012 and in the autumn and spring of both replicate years (Fig. 7).

\section{Effects of propolis on Vg levels}

$\mathrm{Vg}$ gene expression was measured as a marker of bee nutritional status. In the first replicate, $\mathrm{Vg}$ was expressed at similar levels between treatment groups in July 2012, and by September 2012, bees from the propolis envelope treatment had significantly lower levels of $\mathrm{Vg}$ compared with those from the control colonies $\left(F_{1,16}=10.23, P=0.005\right.$; Fig. 8A). In September 2013, no significant difference in the expression of $\mathrm{Vg}$ was observed between treatment groups (Fig. 8B). By May of both 2013 and 2014, bees in the propolis envelope treatment group showed significantly higher transcription of $\operatorname{Vg}\left(F_{1,9}=9.21, P=0.03\right.$; and $F_{1,9}=8.07, P=0.02$, respectively; Fig. $8 \mathrm{~A}, \mathrm{~B})$.

\section{Seasonal antimicrobial activity of propolis}

Honey bees in Minnesota do not forage for resin (or for any resources) from October to April. Therefore, we tested whether the resin deposited within the hive in September maintained its bioactivity over the winter, until April of the following year. Propolis samples collected from within colonies in October had higher inhibitory activity (significantly lower $\mathrm{IC}_{50}$ value, $87 \mathrm{mg} \mathrm{l}^{-1}$ ) against the bacterial pathogen $P$. larvae, compared with propolis
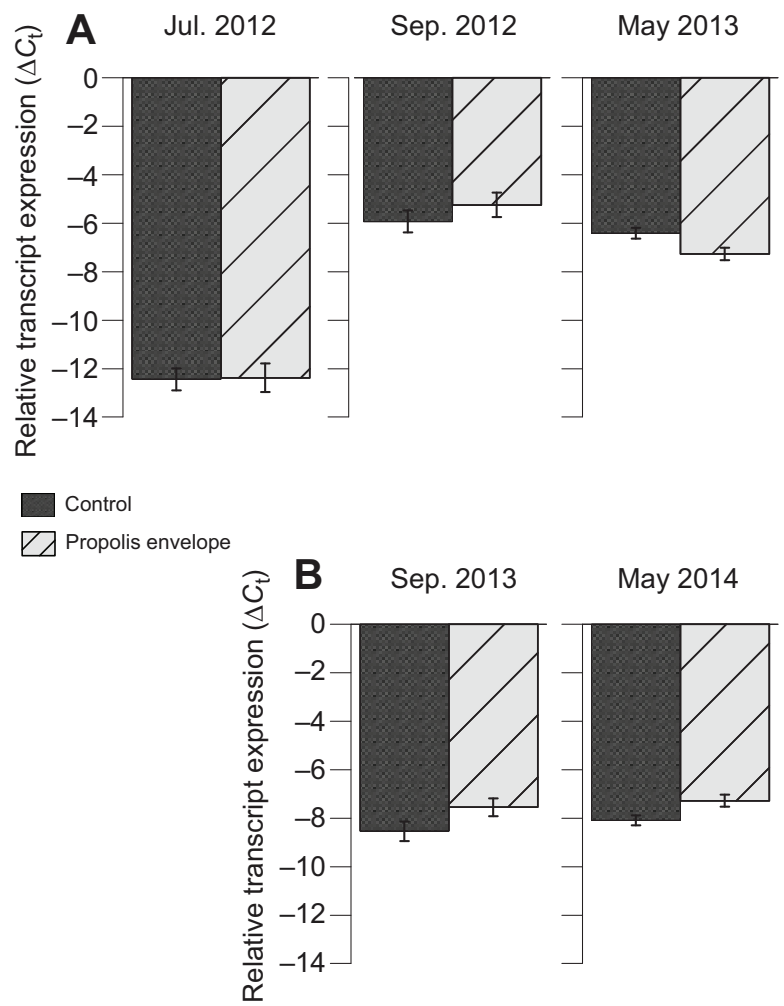

Fig. 7. Colony bacterial load. Relative expression levels of the eubacterial $16 S$ gene (means \pm s.e.m.), normalized to the reference genes actin and RPS-5 ( $N=20$ biological replicates per colony and 6 colonies per treatment) for (A) July 2012, September 2012 and May 2013, and (B) September 2013 and May 2014 for controls and propolis envelope treatment colonies.

samples from the same colonies collected the following April. Fig. 9 shows that propolis samples collected in April had significantly lower inhibitory activity against $P$. larvae growth $\left(\mathrm{IC}_{50}=207 \mathrm{mg} \mathrm{l}^{-1}\right.$, $\left.t_{4}=3.54, P=0.02\right)$.

\section{DISCUSSION}

This is the first study of the seasonal effects of a natural propolis envelope on the immune system of honey bees. Our results from summer and autumn extend those of Simone et al. (2009), who reported a decrease in the expression of two immune-related genes in bees after only 7 days' exposure to propolis-extract solution experimentally coated inside the walls of small colonies. Organic solvent extracts of propolis may not contain all active compounds, and this is not how bees are exposed to propolis naturally; thus, we allowed the bees to construct their own propolis envelope. We found the natural propolis envelope served to lower immune gene transcription in individual bees over the summer and autumn months. The immune system is one of the most costly physiological systems to maintain in animals (Evans and Pettis, 2005; SchmidHempel, 2005). Therefore, a decrease in energetic costs associated with the maintenance of an up-regulated immune system will help bees to allocate their energy to perform vital tasks (e.g. foraging, rearing brood) and to maintain higher storage protein levels required for overwintering success. After winter, before the bees were actively collecting resin again, we found the propolis within the nest had lost much of its antimicrobial activity from the previous autumn. Correspondingly, there were no significant differences between bees from the two treatment groups in transcript levels of most immune genes in May 2013 and May 2014, with the exception of three genes (defensin-1, relish and phenoloxidase), levels of 
A

\section{Jul. $2012 \quad$ Sep. $2012 \quad$ May 2013}

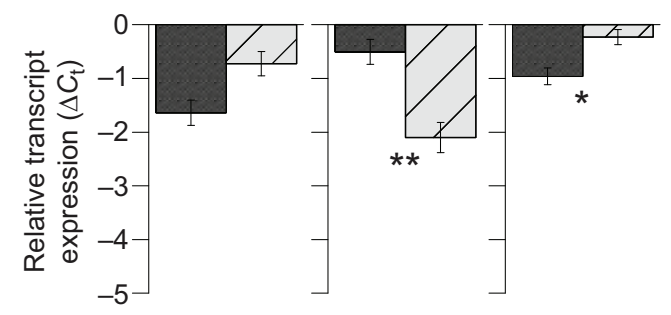

B Sep. $2013 \quad$ May 2014
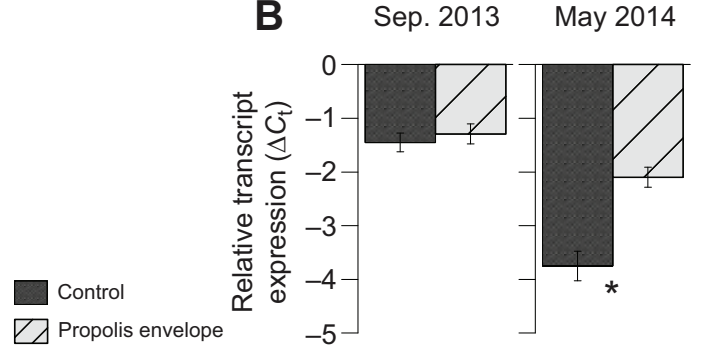

Fig. 8. Colony nutritional status. Relative expression levels of vitellogenin (means \pm s.e.m.),normalized to the reference genes actin and RPS-5 ( $N=20$ biological replicates per colony and 6 colonies per treatment) for (A) July 2012, September 2012 and May 2013, and (B) September 2013 and May 2014 for control and propolis envelope treatment colonies. Significant differences between groups, determined by two-tailed $t$-test with colonies as random variables, are indicated by asterisks $\left({ }^{*} P<0.05,{ }^{* *} P<0.01\right)$.

which were significantly higher in May 2013 in bees from colonies with a propolis envelope. The presence of a natural propolis envelope within the nest corresponded to greater colony survivorship in the first replicate year and greater brood area in the spring of 2013. There were no differences in brood area between groups in May 2014, but Vg levels, an indicator of nutritional health, were significantly higher in both May 2013 and May 2014 in bees from colonies with a propolis envelope compared with those from control colonies. The levels of pathogens, including viruses and parasitic mites (Varroa destructor), did not differ between colonies in the

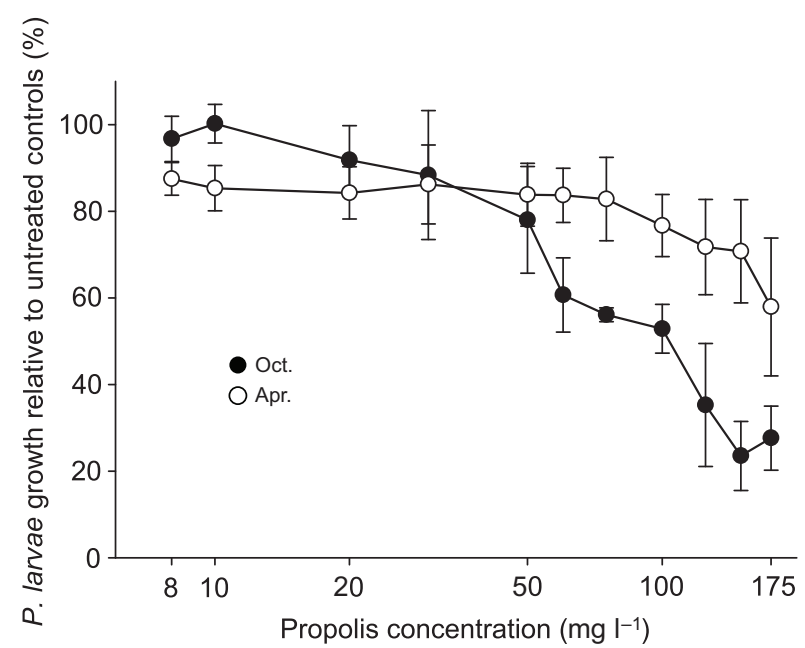

Fig. 9. Dose responsiveness of Paenibacillus larvae growth to propolis extracts collected in October and April. Paenibacillus larvae growth was measured as percentage optical density $\left(\mathrm{OD}_{600}\right)$ relative to untreated controls. Propolis concentration $\left(\mathrm{mg} \mathrm{l}^{-1}\right)$ is shown in a $\log _{10}$ scale. Statistical analysis is from a two-tailed $t$-test comparing $\mathrm{IC}_{50}$ values between the two sampling periods. two treatment groups. In contrast to previous findings (Simone et al., 2009), eubacterial 16S gene expression did not differ in bees from colonies with or without a propolis envelope. It was previously hypothesized that the propolis benefited the honey bee immune system indirectly, first by lowering the amount of microbes within the nest and subsequently by lowering immune gene transcription (Simone et al., 2009). Our current findings suggest that the propolis envelope may have an additional direct effect on the immune system.

Honey bees have several layers of defense mechanisms: the individual immune system response, behavioral immune defenses (e.g. hygienic behavior or grooming), antimicrobial secretions (e.g. royal jelly and venom), and the collection of antimicrobial compounds (resin) from the environment (Evans and Spivak, 2010). The active collection and deposition of antimicrobial plant resins, or propolis, in the nest architecture produces a colony-level immune phenotype, or social immunity (Cremer et al., 2007; Simone et al., 2009). The physical presence of a propolis envelope in the nest architecture is an additional layer of defense for the colony; it is an external antimicrobial barrier that has a direct effect on the baseline expression of immune-related genes of individual bees. The propolis envelope may be considered as an environmentally derived component of the bee's defense mechanism.

The insect immune system is composed of both humoral and cellular immune responses. The humoral immune response includes the biosynthesis of antimicrobial peptides (AMPs) via signaling pathways (Toll, IMD, Jak-STAT; Evans et al., 2006). Cell-mediated immune responses involve hemocyte-associated defenses. These cellular defense mechanisms include phagocytosis, encapsulation and nodulation, which are often followed by a cell-associated response of melanization via the activation of the phenoloxidase cascade in hemocytes (Söderhäll and Cerenius, 1998; Strand, 2008). Our study demonstrates that the effect of propolis on the honey bee immune system occurs both on humoral immunity (AMP expression) and on cellular immunity (phenoloxidase activation cascade). Two AMPs (hymenoptaecin and abaecin) were consistently low in bees from the propolis envelope treatment during summer and autumn in 2012 and autumn of 2013. Additionally, defensin-1, defensin-2, relish and phenoloxidase showed significantly lower expression in September 2012. The same trend was present in September 2013 for defensin-1, defensin2 and phenoloxidase, although not significantly different. It remains to be determined whether a few key genes play a more important role in honey bee immunity than others (e.g. AMPs versus phenoloxidase), although it has been hypothesized that it is less costly for insects, under high risk of infection (such as in social insect nest environments), to invest in AMP synthesis compared with maintaining the phenoloxidase cascade active (Moret, 2003). If verified, it could explain the consistently higher expression of hymenoptaecin and abaecin in July and September 2012, and September 2013 in bees from control colonies than in bees from colonies with a propolis envelope.

The direct effect of propolis on immune cells of vertebrates has been well studied (reviewed in Sforcin, 2007). Propolis has been shown to increase macrophage microbicidal activity (Salomão et al., 2004), enhance the lytic activity of lymphocytes (Kaneno, 2005), and decrease lymphoproliferation (Sá-Nunes et al., 2003) in mice and humans, in vivo and in vitro, respectively. The mode of action by which propolis may regulate immune gene expression in honey bees is unknown. It is possible that, similar to vertebrates, propolis increases cellular immune responses and indirectly decreases the activation of the humoral immune response cascade. Our study did 
not assess the antimicrobial activity of propolis on bee hemocytes directly. Further investigations will contribute to a better understanding of the immune-modulatory mode of action of propolis on the immune systems of social insects.

We found a decrease in the inhibitory activity on $P$. larvae growth of propolis samples collected in the spring compared with those from the previous autumn. These results suggest that propolis loses its bioactivity over the winter, when collection of resin ceases until plant sources of resin have new growth and produce new resin when environmental temperatures are favorable. As a result, it is plausible to assume that in the spring of the following year, the direct effect of propolis on the immune system of honey bees is minimal, if any. The transcription of defensin-1, relish and phenoloxidase was significantly higher in bees from colonies with a propolis envelope than in bees in control colonies in May 2013 but not in May 2014. We do not have a clear explanation of why these three immune genes were significantly higher in May 2013 in the propolis envelope treatment group. Little is known about the immune system response in spring bees compared with summer and autumn bees. Future research exploring the baseline expression of bee immune genes in the spring would greatly contribute to our understanding of the natural seasonal variation of the immune system response.

There was a significant seasonal variation in immune gene transcription from summer to the following spring in 2012-2013 and from autumn to the following spring in 2013-2014. Dawkins et al. (2013) support the hypothesis that an important indicator of a healthy population is represented by more uniformity, or low variance, in the health-related measures. Unhealthy individuals contribute to a wider spread of the population data while healthy populations present a more narrow range of results (Dawkins et al., 2013). Here, we found that in both years of this study, the seasonal variation in gene transcription was significantly lower, and thus more uniform, in bees from the propolis envelope treatment colonies for the majority of the genes analyzed, potentially representing a healthier population. It may be that the most important function of the propolis envelope is to modulate costly immune system activity.

Our original hypothesis was that eubacterial load (as measured by $16 \mathrm{~S}$ rRNA gene expression) would be lower in propolis envelope colonies based on previous findings of Simone et al. (2009). However, our results showed no significant differences in eubacterial gene expression between the groups in either replicate year. Although the main research interest of our experiment and that of Simone et al. (2009) was similar, these two studies differed in the size of experimental colonies, and the duration of the experiment and type of propolis (extract versus natural), which could have led to slightly different results. Nonetheless, both studies found that bees in propolis-rich colonies had a lower immune gene expression compared with bees in propolis-poor (control) colonies. The lack of difference in pathogen and bacteria levels between treatment groups but a significant decrease in immune gene expression in bees from propolis envelope colonies suggests a direct effect of propolis on the bee immune system. The $16 \mathrm{~S}$ ribosomal RNA sequence is highly conserved among bacteria species (Stackebrandt and Goebel, 1994), and thus a primer designed for this gene will bind to most bacterial DNA present in the honey bee ( pathogenic, beneficial, commensals and fortuitous). Given that honey bees have a large number of bacterial symbionts located in the honey stomach (Olofsson et al., 2014), our results may represent the level of not only pathogenic but also beneficial bacterial strains. Future studies investigating specific bacterial strains will be needed to elucidate the effect of the propolis envelope on honey bee microbiota and pathogenic microbes.
There is strong evidence that RNA interference (RNAi) plays a major role in honey bee defense against viral infections (Desai et al., 2012; Flenniken and Andino, 2013; Maori et al., 2009). However, there is contradictory evidence concerning the role of humoral immunity in combating viral infection. Azzami et al. (2012) reported that antimicrobial peptide (e.g. hymenoptaecin and abaecin) expression is not altered upon viral challenge, while a more recent study showed that IAPV infection up-regulates multiple immune signaling pathways in adult bees (Chen et al., 2014). In our study, the lack of a significant difference in viral level between treatments, in both replicate years, strongly indicates that the differences in immune system activity observed are not due to viral infection. The propolis treatment did not appear to have antiviral activity (except for the marginal activity against BQCV only, in May 2014), although it has been reported that some viruses are more susceptible to propolis than others in vitro (Amoros et al., 1992; Kujumgiev et al., 1999). The antiviral activity of propolis against human viruses is well documented in human cell culture (Amoros et al., 1992; Gekker et al., 2005; Kujumgiev et al., 1999; Schnitzler et al., 2010). Viruses are obligate intracellular parasites and they must enter host cells in order to live and reproduce. Schnitzler et al. (2010) suggested that the chemical compounds of propolis decrease HSV-1 viral infection in vitro by binding to important viral proteins responsible for the adsorption or entry of the virus into the host cell. Additionally, pre-treatment of herpes virus with propolis prior to infection increased the antiviral effect of propolis in vitro (Amoros et al., 1994; Schnitzler et al., 2010). One common viral infection route in honey bees is via ingestion of pathogen-contaminated food resources (Chen et al., 2006). It is not known whether bees ingest propolis, or whether bees add propolis to food materials stored in combs (e.g. pollen, honey). If they do, viruses might come into contact with propolis prior to infection (Simone-Finstrom and Spivak, 2010). Further studies will be necessary to understand the mode of action of propolis against intracellular parasites, such as viruses and Nosema spp.

Our study aimed to investigate the effects of the honey bees' natural defense mechanism under normal field conditions. Thus, although pathogen levels were similar between treatment groups each year, differences in the intensity of naturally occurring pathogens and parasites occurred between years. Levels of Varroa mites and DWV were significantly higher in September 2013 than in September 2012, and Varroa, Nosema spp. and BQCV levels were significantly higher in May 2014 than in May 2013 (Table S2). In general, higher levels of parasite, pathogen and virus were detected in colonies during the 2013-2014 study year, which could have contributed to the presence of slightly different patterns of gene expression levels between replicate years.

Although there is evidence that propolis has activity against the parasitic mite Varroa destructor (Damiani et al., 2010; Garedew et al., 2002), the bioactivity of propolis was observed only in laboratory conditions and we did not note any effect of the propolis on Varroa levels in the field. The lack of a significant difference in the levels of Varroa mites in May between control and propolis envelope colonies was expected as all colonies received miticide treatment before the winter. The seasonal dynamics of Varroa infection intensity was in accordance with previous studies (Rosenkranz et al., 2010), with rising levels of Varroa mites from summer to autumn.

At the colony level, we found that the presence of a natural propolis envelope within the nest corresponded to greater colony survivorship at the end of the first experimental year but not in the second year. In the first replicate year, four colonies from the control 
treatment experienced a sudden decline in the summer (two colonies in June and the other two in July) and one colony from each treatment group died before the winter. The cause of death of these colonies was undetermined. Although the number of colonies lost during the winter in both replicate years was similar between treatments, overall survivorship was significantly higher in the first replicate year in the group of colonies that had a propolis envelope. Additionally, we found that colonies with a propolis envelope had greater brood areas in the spring of one year and slightly, but not significantly, more brood in May 2014. These results are supported by Nicodemo et al. (2014), who found that high-propolis-producing colonies had significantly more brood compared with low-propolisproducing colonies. We also found that bees from the propolis envelope colonies had significantly higher levels of Vg in May 2013 and 2014. The high Vg levels in bees from propolis envelope colonies in the spring of both replicate years suggest that these bees had more protein storage in the spring compared with bees in control colonies and, therefore, were able to rear more brood than control colonies. Vg level is a good marker of nutritional status; it is the main storage protein for young bees (approximately 40\% of total protein present in the hemolymph; Engels et al., 1990) and a precursor for other proteins (Amdam et al., 2003, 2004). It has also been shown that young worker bees, performing the task of feeding young larvae, use Vg during royal jelly synthesis (Amdam et al., 2003). The amount of $\mathrm{Vg}$ in bee hemolymph is positively influenced by the quantity of pollen ingested by bees (Bitondi and Simoes, 1996), and colonies with higher amounts of pollen rear more worker brood in the spring compared with colonies with low pollen or pollen substitute (Mattila and Otis, 2006). The transcription of $\mathrm{Vg}$ was significantly higher in September 2012 in bees from control colonies. The immune gene expression data suggest that bees from the control treatment invested more in immune function than those from the propolis envelope group in September 2012. Therefore, it is possible that the significant high level of $\mathrm{Vg}$ in bees from control colonies in September 2012 is linked to its role in honey bee immunity as a potent zinc carrier and zinc-binding protein and not as a nutritional marker (Amdam et al., 2004).

\section{Conclusion}

This study provides evidence that the incorporation of resin from the environment into the nest architecture in the form of a propolis envelope can benefit honey bees at the colony and individual level. Our results suggest that a propolis envelope within the hive benefits colony strength (e.g. increasing worker brood population) in the spring, which could largely benefit the colony at this crucial time in their life cycle. We also found that the presence of a propolis envelope increased colony survivorship in one year of the study, and directly affected individual health (e.g. decreasing the baseline expression on immune-related genes in the summer and autumn and maintaining a less variable immune system function). Promoting honey bee natural defenses by investigating the general and specific benefits of propolis may lead to novel and sustainable ways to improve bee health and mitigate some losses.

\section{Acknowledgements}

We would like to thank Gary Reuter, from the University of Minnesota, for assistance with honey bee colony management, Dr Brad Mogen for assistance with honey bee viral quantitative PCR analysis, and the contribution of undergraduate students of the BEE course (Bees Enhancing Education) at the University of Wisconsin-River Falls, to this study during their research training. We also acknowledge the support of all the members of the Bee Lab at the University of Minnesota.

\section{Competing interests}

The authors declare no competing or financial interests.

\section{Author contributions}

R.S.B. and M.S. conceived and designed the experiment. R.S.B., M.S., K.K.K. and K.L.M. performed the experiment. R.S.B. analyzed the data. R.S.B. and M.S. interpreted the data and wrote the manuscript.

\section{Funding}

This research was funded by the National Science Foundation IOS 1256992 to M.S., with additional support from the North Central Region - Sustainable Agriculture Research and Education (NCR-SARE) graduate student grant, the North American Pollinator Protection Campaign (NAPPC), the National Honey Board, and Project Apis $\mathrm{m}$. We also acknowledge the donations of beekeeping equipment for this study from Mann Lake Ltd, MN, USA.

\section{Supplementary information}

Supplementary information available online at http://jeb.biologists.org/lookup/suppl/doi:10.1242/jeb.127324/-/DC1

\section{References}

Amdam, G. V., Norberg, K., Hagen, A. and Omholt, S. W. (2003). Social exploitation of vitellogenin. Proc. Natl. Acad. Sci. 100, 1799-1802.

Amdam, G. V., Simões, Z. L. P., Hagen, A., Norberg, K., Schrøder, K. Mikkelsen, Ø., Kirkwood, T. B. L. and Omholt, S. W. (2004). Hormonal control of the yolk precursor vitellogenin regulates immune function and longevity in honeybees. Exp. Gerontol. 39, 767-773.

Amdam, G. V., Aase, A. L. T. O., Seehuus, S.-C., Kim Fondrk, M., Norberg, K. and Hartfelder, K. (2005). Social reversal of immunosenescence in honey bee workers. Exp. Gerontol. 40, 939-947.

Amoros, M., Sauvager, F., Girre, L. and Cormier, M. (1992). In vitro antiviral activity of propolis. Apidologie 23, 231-240.

Amoros, M., Lurton, E., Boustie, J., Girre, L., Sauvager, F. and Cormier, M. (1994). Comparison of the anti-herpes simplex virus activities of propolis and 3-methyl-but-2-enyl caffeate. J. Nat. Prod. 57, 644-647.

Antúnez, K., Harriet, J., Gende, L., Maggi, M., Eguaras, M. and Zunino, P. (2008). Efficacy of natural propolis extract in the control of American foulbrood. Vet. Microbiol. 131, 324-331.

Arathi, H. S., Burns, I. and Spivak, M. (2000). Ethology of hygienic behaviour in the honey bee Apis mellifera L. (Hymenoptera: Apidae): Behavioural repertoire of hygienic bees. Ethology 106, 365-379.

Azzami, K., Ritter, W., Tautz, J. and Beier, H. (2012). Infection of honey bees with acute bee paralysis virus does not trigger humoral or cellular immune responses. Arch. Virol. 157, 689-702.

Baracchi, D., Francese, S. and Turillazzi, S. (2011). Beyond the antipredatory defence: Honey bee venom function as a component of social immunity. Toxicon 58, 550-557.

Bastos, E. M. A. F., Simone, M., Jorge, D. M., Soares, A. E. E. and Spivak, M. (2008). In vitro study of the antimicrobial activity of Brazilian propolis against Paenibacillus larvae. J. Invertebr. Pathol. 97, 273-281.

Bilikova, K., Popova, M., Trusheva, B. and Bankova, V. (2013). New antiPaenibacillus larvae substances purified from propolis. Apidologie 44, 278-285.

Bitondi, M. M. G. and Simoes, Z. L. P. (1996). The relationship between level of pollen in the diet, vitellogenin and juvenile hormone titres in Africanized Apis mellifera workers. J. Apic. Res. 35, 27-36.

Boncristiani, H., Underwood, R., Schwarz, R., Evans, J. D., Pettis, J. vanEngelsdorp, D. (2012). Direct effect of acaricides on pathogen loads and gene expression levels in honey bees Apis mellifera. J. Insect Physiol. 58 613-620

Chen, Y., Evans, J. and Feldlaufer, M. (2006). Horizontal and vertical transmission of viruses in the honey bee, Apis mellifera. J. Invertebr. Pathol. 92, 152-159.

Chen, Y. P., Pettis, J. S., Corona, M., Chen, W. P., Li, C. J., Spivak, M., Visscher, P. K., DeGrandi-Hoffman, G., Boncristiani, H., Zhao, Y. et al. (2014). Israel acute paralysis virus: epidemiology, pathogenesis and implications for honey bee health. PLoS Pathog. 10, e1004261.

Cremer, S., Armitage, S. A. O. and Schmid-Hempel, P. (2007). Social immunity Curr. Biol. 17, R693-R702.

Damiani, N., Fernández, N. J., Maldonado, L. M., Álvarez, A. R., Eguaras, M. J. and Marcangeli, J. A. (2010). Bioactivity of propolis from different geographical origins on Varroa destructor (Acari: Varroidae). Parasitol. Res. 107, 31-37.

Dawkins, M. S., Cain, R., Merelie, K. and Roberts, S. J. (2013). In search of the behavioural correlates of optical flow patterns in the automated assessment of broiler chicken welfare. Appl. Anim. Behav. Sci. 145, 44-50.

Desai, S. D., Eu, Y.-J., Whyard, S. and Currie, R. W. (2012). Reduction in deformed wing virus infection in larval and adult honey bees (Apis mellifera L.) by doublestranded RNA ingestion. Insect Mol. Biol. 21, 446-455.

Engels, W., Kaatz, H., Zillikens, A., Simões, Z. L. P., Trube, A., Braun, R. and Dittrich, F. (1990). Honey bee reproduction: vitellogenin and caste-specific regulation of fertility. In Advances in Invertebrate Reproduction (ed. M. Hoshi and O. Yamashita), pp. 495-502. Amsterdam: Elsevier. 
Evans, J. D. and Pettis, J. S. (2005). Colony-level impacts of immune responsiveness in honey bees, Apis mellifera. Evolution 59, 2270-2274

Evans, J. D. and Spivak, M. (2010). Socialized medicine: individual and communa disease barriers in honey bees. J. Invertebr. Pathol. 103, S62-S72.

Evans, J. D., Aronstein, K., Chen, Y. P., Hetru, C., Imler, J.-L., Jiang, H., Kanost, M., Thompson, G. J., Zou, Z. and Hultmark, D. (2006). Immune pathways and defence mechanisms in honey bees Apis mellifera. Insect Mol. Biol. 15, 645-656.

Flenniken, M. L. and Andino, R. (2013). Non-specific dsRNA-mediated antiviral response in the honey bee. PLoS ONE 8, e77263.

Garedew, A., Lamprecht, I., Schmolz, E. and Schricker, B. (2002). The varroacidal action of propolis: a laboratory assay. Apidologie 33, 41-50.

Gekker, G., Hu, S., Spivak, M., Lokensgard, J. R. and Peterson, P. K. (2005). Anti-HIV-1 activity of propolis in CD4+ lymphocyte and microglial cell cultures. J. Ethnopharmacol. 102, 158-163.

Human, H., Brodschneider, R., Dietemann, V., Dively, G., Ellis, J. D., Forsgren, E., Fries, I., Hatjina, F., Hu, F.-L., Jaffé, R. et al. (2013). Miscellaneous standard methods for Apis mellifera research. J. Apic. Res. 52, 1-56.

Johnson, R. M., Wen, Z., Schuler, M. A. and Berenbaum, M. R. (2006). Mediation of pyrethroid insecticide toxicity to honey bees (Hymenoptera: Apidae) by cytochrome P450 monooxygenases. J. Econ. Entomol. 99, 1046-1050.

Johnson, R. M., Mao, W., Pollock, H. S., Niu, G., Schuler, M. A. and Berenbaum, M. R. (2012). Ecologically appropriate xenobiotics induce cytochrome P450s in Apis mellifera. PLoS ONE 7, e31051.

Kaneno, R. (2005). Role of natural killer cells in antitumor resistance. Annu. Rev. Biomed. Sci. 7, 127-148.

Kujumgiev, A., Tsvetkova, I., Serkedjieva, Y., Bankova, V., Christov, R. and Popov, S. (1999). Antibacterial, antifungal and antiviral activity of propolis of different geographic origin. J. Ethnopharmacol. 64, 235-240.

Langenheim, J. H. (2003). Plant Resins: Chemistry, Evolution, Ecology, and Ethnobotany. Portland, OR: Timber Press.

Lee, K. V., Moon, R. D., Burkness, E. C., Hutchison, W. D. and Spivak, M. (2010) Practical sampling plans for Varroa destructor (Acari: Varroidae) in Apis mellifera (Hymenoptera: Apidae) colonies and apiaries. J. Econ. Entomol. 103, 1039-1050.

Lindenfelser, L. A. (1968). In vivo activity of propolis against Bacillus larvae. J. Invertebr. Pathol. 12, 129-131.

Mao, W., Schuler, M. A. and Berenbaum, M. R. (2011). CYP9Q-mediated detoxification of acaricides in the honey bee (Apis mellifera). Proc. Natl. Acad. Sci. USA 108, 12657-12662.

Maori, E., Paldi, N., Shafir, S., Kalev, H., Tsur, E., Glick, E. and Sela, I. (2009) IAPV, a bee-affecting virus associated with colony collapse disorder can be silenced by dsRNA ingestion. Insect Mol. Biol. 18, 55-60.

Mattila, H. R. and Otis, G. W. (2006). Influence of pollen diet in spring on development of honey bee (Hymenoptera: Apidae) colonies. J. Econ. Entomol. 99, 604-613.

Moret, Y. (2003). Explaining variable costs of the immune response: selection for specific versus non-specific immunity and facultative life history change. Oikos 102, 213-216.

Nasr, M. E., Thorp, R. W., Tyler, T. L. and Briggs, D. L. (1990). Estimating honey bee (Hymenoptera: Apidae) colony strength by a simple method: measuring cluster size. J. Econ. Entomol. 83, 748-754.

Naug, D. and Smith, B. (2007). Experimentally induced change in infectious period affects transmission dynamics in a social group. Proc. R. Soc. B Biol. Sci. 274 61-65.

Nicodemo, D., De Jong, D., Couto, R. H. N. and Malheiros, E. B. (2013). Honey bee lines selected for high propolis production also have superior hygienic behavior and increased honey and pollen stores. Genet. Mol. Res. 12, 6931-6938

Nicodemo, D., Malheiros, E. B., De Jong, D. and Couto, R. H. N. (2014) Increased brood viability and longer lifespan of honeybees selected for propolis production. Apidologie 45, 269-275.
Olofsson, T. C., Butler, É., Markowicz, P., Lindholm, C., Larsson, L. and Vásquez, A. (2014). Lactic acid bacterial symbionts in honeybees - an unknown key to honey's antimicrobial and therapeutic activities. Int. Wound J. doi:10.1111/ iwj. 12345.

Otti, O., Tragust, S. and Feldhaar, H. (2014). Unifying external and internal immune defences. Trends Ecol. Evol. 29, 625-634.

Rademacher, E. and Harz, M. (2006). Oxalic acid for the control of varroosis in honey bee colonies - a review. Apidologie 37, 98-120.

Rosenkranz, P., Aumeier, P. and Ziegelmann, B. (2010). Biology and control of Varroa destructor. J. Invertebr. Pathol. 103, S96-S119.

Salomão, K., Dantas, A. P., Borba, C. M., Campos, L. C., Machado, D. G., Aquino Neto, F. R. and Castro, S. L. (2004). Chemical composition and microbicidal activity of extracts from Brazilian and Bulgarian propolis. Lett. Appl. Microbiol. 38, 87-92.

Sá-Nunes, A., Faccioli, L. H. and Sforcin, J. M. (2003). Propolis: lymphocyte proliferation and IFN- $\gamma$ production. J. Ethnopharmacol. 87, 93-97.

Schmid-Hempel, P. (2005). Evolutionary ecology of insect immune defenses. Annu. Rev. Entomol. 50, 529-551.

Schnitzler, P., Neuner, A., Nolkemper, S., Zundel, C., Nowack, H., Sensch, K. H. and Reichling, J. (2010). Antiviral activity and mode of action of propolis extracts and selected compounds. Phytother. Res. 24, S20-S28.

Seeley, T. D. (1989). The honey bee colony as a superorganism. Am. Sci. 77 546-553.

Seeley, T. D. and Morse, R. A. (1976). The nest of the honey bee (Apis mellifera L.). Insects Soc. 23, 495-512.

Sforcin, J. M. (2007). Propolis and the immune system: a review. J. Ethnopharmacol. 113, 1-14

Simone, M., Evans, J. D. and Spivak, M. (2009). Resin collection and socia immunity in honey bees. Evolution 63, 3016-3022.

Simone-Finstrom, M. and Spivak, M. (2010). Propolis and bee health: the natura history and significance of resin use by honey bees. Apidologie 41, 295-311.

Simone-Finstrom, M. D. and Spivak, M. (2012). Increased resin collection after parasite challenge: a case of self-medication in honey bees? PLOS ONE 7 , e34601

Söderhäll, K. and Cerenius, L. (1998). Role of the prophenoloxidase-activating system in invertebrate immunity. Curr. Opin. Immunol. 10, 23-28.

Spivak, M. and Reuter, G. S. (2001). Varroa destructor infestation in untreated honey bee (Hymenoptera: Apidae) colonies selected for hygienic behavior. J. Econ. Entomol. 94, 326-331.

Stackebrandt, E. and Goebel, B. M. (1994). Taxonomic note: a place for DNA-DNA reassociation and $16 \mathrm{~S}$ rRNA sequence analysis in the present species definition in bacteriology. Int. J. Syst. Bacteriol. 44, 846-849.

Strand, M. R. (2008). Insect hemocytes and their role in immunity. In Insect Immunology (ed. N. Beckage), pp. 25-47. Boston: Academic Press.

Stroeymeyt, N., Jordan, C., Mayer, G., Hovsepian, S., Giurfa, M. and Franks, N. R. (2014). Seasonality in communication and collective decision-making in ants. Proc. R. Soc. B Biol. Sci. 281, 20133108.

Wilson, M. B., Spivak, M., Hegeman, A. D., Rendahl, A. and Cohen, J. D. (2013). Metabolomics reveals the origins of antimicrobial plant resins collected by honey bees. PLOS ONE 8, e77512

Wilson, M. B., Brinkman, D., Spivak, M., Gardner, G. and Cohen, J. D. (2015) Regional variation in composition and antimicrobial activity of US propolis against Paenibacillus larvae and Ascosphaera apis. J. Invertebr. Pathol. 124, 44-50.

Wilson-Rich, N., Dres, S. T. and Starks, P. T. (2008). The ontogeny of immunity: development of innate immune strength in the honey bee (Apis mellifera). J. Insect Physiol. 54, 1392-1399. 